\title{
ANALISIS KESESUAIAN PENERAPAN STANDAR AKUNTANSI KEUANGAN SYARIAH UNTUK PEMBIAYAAN MURABAHAH DENGAN PSAK NOMOR 102 PADA LEMBAGA KEUANGAN MIKRO SYARIAH DI ACEH BESAR
}

\author{
Nurlaili Maghfirah $^{1}$, Evi Mutia $^{* 2}$, Dinaroe ${ }^{3}$ \\ ${ }^{1,2}$ Program Studi Akuntansi Fakultas Ekonomi Universitas Syiah Kuala

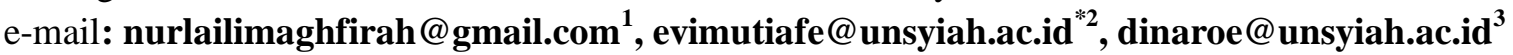 \\ * Corresponding Author
}

\begin{abstract}
This study aims to examine the implementation of Statement of Financial Accounting Standards (PSAK) Number 102 concerning murabahah financing in Sharia Cooperatives in Aceh Besar and determine the suitability of the application of PSAK 102 on murabahah financing in Sharia Cooperatives in Aceh Besar. The population of this research is 6 Sharia Cooperatives in Aceh Besar which are registered at the Office of Cooperatives and Small and Medium Micro Businesses in Aceh Besar District which are still active until now and which apply murabahah financing. The analysis was conducted by comparing the implementation of accounting treatment on murabahah financing transactions with PSAK 102. The results showed that the accounting treatment of sharia cooperatives in Aceh Besar in terms of recognition and measurement was not fully following PSAK 102, while the accounting treatment on the presentation and disclosure side was following PSAK 102.
\end{abstract}

Keywords: Sharia Cooperative, Murabahah Financing, PSAK 102

\section{Pendahuluan}

Lembaga Keuangan Syariah (LKS) telah berkembang sangat pesat di Indonesia saat ini, untuk memenuhi kebutuhan akan pembiayaan berbasis syariah yang semakin diperlukan oleh mayoritas penduduk Indonesia yang menganut agama Islam. Hal ini untuk memastikan terhindarnya segala unsur yang diharamkan dalam Islam termasuk unsur ribawi. LKS merupakan lembaga keuangan yang beroperasional berdasarkan prinsip syariah (Budiono, 2017). Telah banyak varian LKS di seluruh Indonesia, tidak hanya berupa bank namun juga LKS lainnya seperti Lembaga Keuangan Mikro Syariah (LKMS) yang biasa disebut Baitul Maal wat Tamwil (BMT) atau koperasi syariah.

BMT atau koperasi syariah adalah Lembaga Keuangan Mikro Syariah (LKMS) yang beroperasi dalam bidang simpanan, pembiayaan, dan investasi sesuai dengan prinsip syariah (Hasyim, 2018). BMT juga memiliki tujuan menumbuhkan dan mengembangkan bisnis usaha kecil menengah untuk memberikan kemaslahatan bagi kaum fakir miskin (Darsono, 2017:113).
Selain untuk memberi kesejahteraan bagi anggota koperasi, koperasi syariah juga berfungsi untuk membangun perekonomian yang adil dan merakyat berdasarkan prinsip-prinsip Islam bagi masyarakat luas. Perkembangan koperasi syariah yang terus meningkat didorong untuk terus memberdayakan masyarakat dengan memberikan pembiayaan untuk usaha mikro, kecil, dan menengah (Marlina \& Pratami, 2017). Di Indonesia, koparasi syariah mengalami peningkatan yang sangat baik. Berdasarkan data Kementrian Koparasi dan UKM, total usaha koperasi syariah berjumlah 150.223 unit dengan total anggota tetulis 1,4 juta orang. Jumlah kekayaan koperasi syariah sendiri berjumlah Rp.968 miliar dan jumlah kekayaan luar Rp.3,9 triliun dengan besar usaha Rp.5,2 triliun. (Kementrian Koperasi dan UKM, 2016).

Pertumbuhan koparasi syariah yang sangat baik mendorong tumbuhnya aset dan volume perusahaan dengan menawarkan berbagai pembiayaan. Koperasi syariah biasanya menerapkan beberapa sistem pembiayaan, di antaranya: pembiayaan murabahah, pembiayaan mudharabah, dan pembiayaan 
musyarakah. Jumlah pembiyaan yang diserahkan oleh LKMS di Indonasia dirangkum dalam Tabel 1.

Tabel 1 menggambarkan bahwa jumlah pembiyaan yang paling besar diberikan kepada masyarakat adalah pembiyaan murabahah yaitu sebanyak $76,2 \%$ dari seluruh pembiyaan. Hal ini dikarenakan keuntungan yang diberikan dalam pembiyaan murabahah bersifat sudah ditetapkan dan prosedurnya tidak susah (Sulaiman, 2016). Pembiyaan murabahah merupakan perjanjian jual beli barang dengan mengungkapkan harga pokok ditambah margi yang disetujui oleh pihak-pihak yang bertransaksi. (Nurhayati \& Wasilah, 2015:174).

Terkait transaksi pembiayaan murabahah, terdapat penyimpangan umum yang terjadi di LKS, di antaranya adalah penggunaan akad murabahah pada akad yang bukan seharusnya. Sebagai contoh, pembiyaan untuk pembuatan rumah. Transaksi ini

Tabel 1

Jumlah Pembiyaan yang Diserahkan Lembaga Keuangan Mikro Syariah di Indonesia

\begin{tabular}{|c|c|c|}
\hline Keterangan & Jumlah dalam miliyar & Persentase \\
\hline Mudharabah & 5,80 & $9,1 \%$ \\
\hline Musyarakah & 9,34 & $14,7 \%$ \\
\hline Murabahah & 48,56 & $76,2 \%$ \\
\hline Lain-lain & - & \\
\hline
\end{tabular}

Sumber data: www.ojk.go.id/Desember 2018

tidak seharusnya menggunakan akad murabahah karena tidak terdapat syarat kepunyaan atas barang dan harga yang diketahui. Penyimpangan lainnya yag juga terjadi adalah transaksi murabahah dilakukan sedangkan lembaga tidak memiliki barang yang diinginkan nasabah, hal ini melanggar syarat kepemilikan barang yang seharusnya menjadi syarat yang harus dipenuhi dalam jual beli (Sulaiman, 2016). Jika penyimpangan-penyimpangan tersebut terjadi maka akan menimbulkan unsur riba, yang mana hal ini sangat dilarang dalam Islam.

Penyimpangan-penyimpangan tersebut tidak seharusnya terjadi pada LKS di provinsi Aceh. Hal ini dikarenakan ideologi yang melekat pada provinsi Aceh, bahwasannya penduduk Aceh mayoritas beragama Islam yang memiliki misi memperkuat pelaksanaan syariat Islam beserta nilai-nilai keislaman dalam kehidupan masyarakat. Oleh karena itu, LKS harus beroperasi berdasarkan prinsip Islam, khususnya koperasi syariah.

Koperasi syariah bertujuan untuk mensejahterakan masyarakat, sehingga dalam pengelolaan koperasi syariah harus profesional dengan mempraktikkan konsep kesejahteraan, keterbukaan, akuntabilitas dan transparansi yang dapat diakui, diterima dan dipercaya oleh anggotanya ataupun masyarakat. Koperasi syariah juga diharuskan untuk memiliki kemampuan dalam memberikan informasi akuntansi secara baik dan benar. Informasi akuntansi yang baik merupakan alat yang efektif bagi manajemen koperasi syariah untuk memberikan pengarahan dalam mengendalikan jalannya usaha.

Akuntansi berfungsi menyediakan informasi tentang data keuangan yang berupa angka-angka yang dapat dipergunakan oleh pihak-pihak tertentu yang memiliki kepentingan dalam membuat keputusan ekonomi. Sehingga, akutansi membutuhkan alat ukur untuk mengukur berbeagai transaksi dan peristiwa yang terjadi dalam suatu perusahaan dengan mempraktikkan prosedur yang telah ditetapkan yang bisa diterima oleh pihak-pihak yang berkepentingan. Prosedur-prosedur akuntansi yang belaku untuk umum di Indonasia disebut PSAK (Pernyataan Standar Akuntansi Keuangan), salah satunya adalah PSAK No. 102.

PSAK No. 102 adalah salah satu PSAK yang disahkan DSAKS-IAI dan mulai berlaku pada tahun 2008. PSAK No. 102 ini mengatur alur pencatatan transaksi-transaksi pembiyaan yang menggunakan metode jual beli mulai dari transaksi-transaksi dari pihak penjual dan pembeli menjadi sistem akutansi yang digunakan di LKS (iaiglobal, 2018).

Berdasarkan Keputusan Menteri Negara Koperasi dan Usaha Kecil dan Menengah Republik Indonesia Nomor: 91/Kep/M.Ku/KM/IX/2004 Tentang Petunjuk Pelaksanaan Kegiatan Usaha Koperasi Jasa Keuangan Syariah bahwasannya koperasi syariah diharuskan untuk membuat laporan keuangan yang sesuai dengan PSAK Syariah. Akan tetapi, masih ada koperasi syariah yang belum 
menyesuaikan proses akuntansi dengan PSAK Syariah. Salah satunya adalah penelitian yang dilakukan oleh Ikhsan dan Haridhi (2017) pada koperasi syariah atau Baitul Qiradh di Kota Banda Aceh yang merupakan ibu kota provinsi Aceh. Hasil penelitian menyatakan bahwa proses pengakuan, pengukuran, penyajian dan pengungkapan pembiayaan murabahah di Baitul Qiradh di Kota Banda Aceh belum sesuai dengan PSAK 102 tentang akuntansi murabahah.

Berdasarkan pemaparan tersebut, penulis tertarik untuk meneliti penerapan PSAK 102 pada pembiayaan murabahah di koperasi syariah apakah sudah sesuai atau tidak. Penulis memilih melakukan penelitian secara empiris pada koperasi-koperasi syariah di kabupaten Aceh Besar yaitu salah satu kabupaten yang berada di Provinsi Aceh dan yang paling dekat dengan Kota Banda Aceh.

\section{Kerangka Teoritis}

\section{Lembaga Keuangan Syariah}

Lembaga keuangan (financial institution) adalah entitas yang beroperasi di bidang keuangan, apakah mengumpulkan dana dari masyarakat, menyalurkan dana kepada masyarakat dan/atau jasajasa keuangan lainnya (Mardani, 2015:1). Dalam SK Menkeu RI No. 792 Tahun 1990 dijelaskan bahwasanya lernbaga keuangan merupakan suatu lernbaga yang beroperasi di bidang jasa keuangan yang menghimpun dan menyalurkan dana masyarakat untuk membiyai investasi perusahaan. Namun hal ini tidak membatasi kegiatan usaha lembaga keuangan karena lembaga keuangan juga bisa bergerak dalam kegiatan konsurnsi dan distibusi barang dan jasa (Soemitra, 2015:27-28). Lembaga keuangan syariah adalah lembaga keuangan yang beroperasi berdasarkan ketentuan-ketentuan syariah dan menghindari dari segala unsur yang diharamkan dalam Islam.

Lembaga keuangan syariah ada dua, yaitu lernbaga keuangan bank dan lernbaga keuangan nonbank. Lernbaga keuangan bank adalah lembaga yang kegiatannya bergerak di bidang keuangan seperti perbankan pada umumnya yakni mengumpulkan dana sebagai tabungan dan memberikan dana kepada masyarkat sebagai pembiyaan (Mardani, 2015:2).

Lembaga keuangan nonbank merupakan lembaga yang beroperasi di jasa keuangan baik secara langsung ataupun tidak langsung mengumpulkan dana dari masyarakat dengan cara menerbitkan saham dan memberikannya kepada masyarakat untuk membiyai investasi perusahaan (Mardani, 2015:2). Masingmasing usaha yang tergolong dalam lernbaga keuangan non bank memiliki undang-undang tersendiri yang mengatur kegiatan usahanya. Yang termasuk Lernbaga keuangn syariiah non bank, antara lain:

1. Lembaga Usaha Syariah (Syirkah)

2. Lembaga Dana Pensiun Syariah

3. Lernbaga Asuransi Syariah

4. Lernbaga Pasar Modal Syariah

5. Lernbaga Pegadaian Syariah

6. Lembaga Wakaf

7. Lernbaga Zakat

8. Lembaga Keuangn Mikrro Syariah/Bait al-Mal wa al-Tamwil/Koperasi Syariah

\section{Koperasi Syariah}

Berdasarkan Undang-Undang No.17 Tahun 2012 tentang Perkoperasian, koperasi merupakan suatu lembaga yang dibangun oleh sekelompok orang yang beroperasi dengan memisahkan harta anggotaanggota, yang bergabung dalam koperasi, yang dijadikan simpanan untuk melakukan kegiatan usaha demi mencukupi segala sesuatu yang dibutuhkan bersama baik di segi ekonomi, social, maupun budaya yang sesuai dengan prinsip koperasi. Pengertian lain dari koperasi adalah suatu lembaga yang beranggotakan beberapa orang yang mana masingmasing memiliki tugas dan tanggung jawab serta memiliki asas kerja sama dan asas kekeluargaan (Virtianto dkk., 2018).

Koperasi syariah dapat diartikan menjadi suatu lembaga yang didirikan oleh sekumpulan orang yang beroperasi berdasarkan prinsip koperasi dan prinsip ekonomi syariah. Rizal Yaya (2017:22) menjelaskan bahwa koperasi syariah, Bait mal wa Tamwil (BMT) merupakan lernbaga yang beroperasi dalam skala mikro atau diperuntukkan bagi usaha mikro, kecil, dan menengah. Sama seperti perbankan, koperasi syariah berperan dalam mengumpulkan dan memberikan dana kepada anggotanya dan masyrakat, khususnya usaha ekonomi menengah ke bawah. 


\section{Pembiayaan}

Menurut Undang-undang No. 10 Tahun 1998 Tentang Perubahan Atas Undang-Undang No. 7 Tahun 1992 Tentang perbankan, pembiyaan syariah adalah menyediakan uang sebesar yang diinginkan nasabah berdasarkan kesepakatan antara bank dengan nasabah dan menjadi kewajiban bagi pihak yang dibiayai untuk melunasi uang tersebut setelah jangka waktu yang dtentukan dengan imbalan atau bagi hasil yang telah disepakati. Beberapa pembiayaan yang biasanya diterapkan di perbankan syariah adalah murabahah, mudharabah, musyarakah, istishna', ijarah dan salam.

\section{Pembiayaan Murabahah}

Nurhayati \& Wasilah (2015:196) mendefinisikan murabahah dengan perjanjian jual beli barang yang mana penjual mengungkapkan harga perolehan kepada pembeli ditambah keuntungan yang disepakati oleh pihak-pihak tersebut. Pembayaran barang dapat dilakukan secara kontan atau cicil. Perbedaan jual beli murabahah dengan jual beli lainnya adalah penjual diharuskan mengungkapkan berapa harga perolehan barang yang dibeli secara jelas dan berapa keuntungan yang diinginkan penjual kepada pembeli.

Akad murabahah ada dua jenis, yaitu sebagai berikut (Nurhayati \& Wasilah, 2015:177):

1. Murabahah dengan pesanan

Murabahah dengan pesanan yaitu penjual membeli barang setelah ada pemesanan dari pembeli. Murabahah jenis ini dapat bersifat mengikat atau tidak mengikat. Jika bersifat mengikat, maka pembeli diharuskan untuk membeli barang yang dipesannya dan tidak dapat boleh membatalkannya. Sedangkan murabahah yang bersifat tidak mengikat boleh membatalkan pemesanan. Jika aset murabahah yang telah dibeli oleh penjual mengalami penurunan nilai sebelum diserahkan kepada pembeli maka penurunan nilai tersebut menjadi beban penjual dan akan mengurangi nilai akad.

2. Murabahah tidak dengan pesanan

Murabahah tidak dengan pesanan yaitu penjual tidak memesan terlebih dahulu karena barang sudah dimiliki oleh penjual dan barang dapat dibeli langsung oleh pembeli. Murabahah ini bersifat tidak mengikat.

\section{Pernyataan Standar Akuntansi Keuangan (PSAK) Nomor 102}

PSAK adalah petunjuk untuk mempraktikkan akuntansi di mana penjelasan di dalamnya merangkap hampir semua aspek yang berhubungan dengan akuntansi. Dalam pengumpulannya, sekelompok orang yang memiliki skil akuntansi harus terlibat dan berkumpul dalam suatu lernbaga bernama Ikatan Akuntan Indonesia (IAI). PSAK ini dapat digunakan sebagai petunjuk bagi pelaku akuntansi dalam melakukan segala hal di bidang akuntansi. PSAK No. 102 berisi tentang peraturan-peraturan terkait dengan transaksi jual beli murabahah yang akan memberi petunjuk akuntansi bagi lernbaga keuangn syariah yang memiliki produk-produk yang menggunakan akad murabahah.

\section{Kerangka Pemikiran}

Koperasi syariah merupakan suatu lembaga keuangan mikro syariah yang bertujuan untuk melayani masyarakat ekonomi mikro yang ingin mengembangkan usahanya dalam bentuk pembiayaan untuk usaha-usaha kecil. Proses pelayanan yang relatif mudah dan cepat yang diterapkan di koperasi syariah sehingga memudahkan bagi pengusaha kecil untuk mengembangkan usahanya.

Pembiayaan murabahah adalah salah satu pembiayaan yang banyak disalurkan oleh koperasi syariah dan diminati oleh masyarakat. Sebagian besar koperasi syariah beranggapan bahwa pembiayaan murabahah ini memiliki risiko yang lebih rendah dari pada pembiayaan lainnya sehingga pembiayaan ini lebih banyak ditawarkan kepada masyarakat. Koperasi syariah yang memberi pembiayaan murabahah juga dituntut untuk mempertanggungjawabkan kinerjanya dalam bentuk laporan keuangan yang harus disusun berdasarkan PSAK 102 yang mengatur tentang akuntansi murabahah. PSAK 102 diterapkan untuk entitas yang memberikan pembiayaan murabahah, baik bagi penjual maupun pembeli. PSAK 102 memiliki tujuan untuk mengatur pengakuan, pengukuran, penyajian dan pengungkapan transaksi murabahah.

Berdasarkan penjelasan sebelumnya bahwa PSAK 102 merupakan instrumen analisis yang sangat diperlukan dalam penelitian ini dan alat untuk membandingkan akuntansi murabahah berdasarkan PSAK 102 dengan praktik akuntansi murabahah pada 
koperasi syariah. Analisis dilakukan untuk melihat apakah perlakuan akuntansi pada koperasi-koperasi syariah di Aceh Besar atas pembiayaan murabahah telah sesuai dengan PSAK 102 atau tidak sesuai. Dengan demikian, skema kerangka pemikiran dapat dilihat pada Gambar 1 .

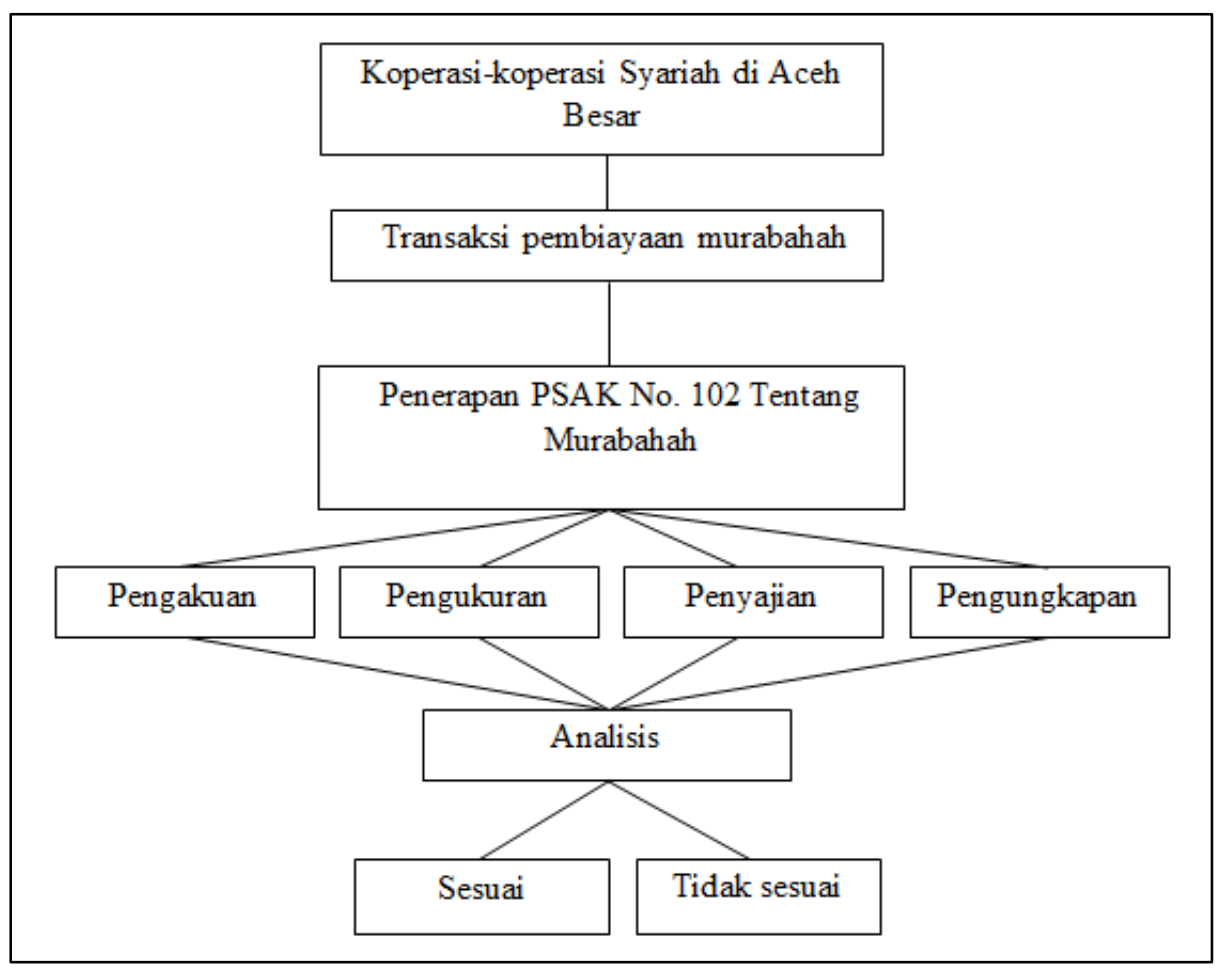

\section{Metode Penelitian}

\section{Desain Penelitian}

Penelitian ini adalah penelitian deskriptif yang bertujuan untuk menjelaskan apakah pengakuan, pengukuran dan penyajian pembiayaan murabahah yang dipraktikkan pada koperasi-koperasi syariah di Aceh Besar telah sesuai dengan PSAK No. 102 tentang pembiayaan murabahah. Jenis penelitian yang digunakan dalam penelitian ini adalah penelitian kualitatif dengan pendekatan deskriptif. Tingkat intervensi dalam penelitian ini penulis menggunakan tingkat intervensi minimal, yakni penulis hanya mengumpulkan data dari koperasi syariah dan tidak melakukan tindakan sehingga akan mempengaruhi hasil penelitian.

Situasi penelitian yang digunakan penulis adalah situasi alami atau situasi normal. Unit analisis dari penelitian ini adalah koperasi syariah di Aceh Besar. Horizon waktu dalam penelitian ini adalah cross-sectional. Dalam penelitian ini, data dikumpulkan hanya sekali yaitu laporan periode tahun 2018.

\section{Objek Penelitian}

Objek penelitian dari penelitian ini adalah koperasi syariah di Aceh Besar yang tercatat pada Dinas Koperasi dan Usaha Mikro Kecil Menengah (UMKM) Kabupaten Aceh Besar yang masih aktif dan yang menerapkan pembiayaan murabahah. Koperasi syariah yang menjadi objek penelitian adalah sebagai berikut (Dinas Koperasi dan UKM Aceh, 2018):

1) Koperasi Syariah Baitul Qiradh Al-Istiqomah

2) Koperasi Syariah Mandiri Darussalam

3) Koperasi Syariah Mitra Niaga

4) Koperasi Syariah Baitul Qiradh Karya Insan Sejahtera 43

5) Koperasi Simpan pinjam Dana Mandiri Syariah

6) Koperasi syariah Baitul Qiradh Abu Indrapuri

\section{Sumber dan Teknik Pengumpulan Data}

Sumber data yang digunakan adalah data primer. Teknik pengumpulan data dalam penelitian ini adalah:

1. Studi kepustakaan

Sebelum melakukan observasi, penulis terlebih dahulu melakukan pengumpulan data dari bukubuku dan literatur yang berkaitan dengan penerapan PSAK No. 102 di koperasi syariah 
seperti pembiayaan murabahah, PSAK No. 102 dan rujukan tentang koperasi syariah. Data-data tersebut akan dijadikan pedoman untuk melakukan analisis terhadap data yang didapat di lapangan.

2. Studi lapangan

a. Observasi, dilakukan dengan melakukan pengamatan secara langsung pada masingmasing koperasi syariah yang ada di Aceh Besar.

b. Kuesioner, yang akan dibagikan kepada bagian keuangan yang bertanggung jawab terhadap laporan keuangan pada masingmasing koperasi syariah. Setelah semua isian kuesioner terkumpul, maka yang dilakukan selanjutnya adalah menghitung skor (nilai) pada setiap indikator yang bertujuan untuk mengetahui persentase penerapan PSAK 102 pada koperasi syariah. Dalam menetapkan skor, penulis menggunakan formulasi dari Sugiyono (2013:17), dengan untuk jawaban Ya bernilai 1 dan untuk jawaban Tidak bernilai 0 untuk. Formulasinya sebagai berikut:

$$
P R=\frac{S C}{S I} x 100 \%
$$

Dimana:

PR = Presentase Capaian

\section{Teknik Analisis Data}

Teknik analisis data atau metode analisis data yang digunakan dalam penelitian ini adalah metode analisis kualitatif deskiptif. Adapun langkah-langkah teknik analisis data yang dilakukan adalah sebagai berikut:

a. Melakukan pengumpulan data berupa hasil wawancara, hasil kuesioner, laporan keuangan, brosur serta data lainnya yang telah didapatkan dari lapangan. Data tersebut, kemudian

$$
\begin{array}{ll}
\mathrm{SC} & =\text { Jumlah Skor Capaian } \\
\mathrm{SI} & =\text { Jumlah Skor Ideal } \\
100 \% & =\text { Jumlah Tetap }
\end{array}
$$

c. Wawancara, yaitu melakukan komunikasi tanya jawab dengan pihak yang berkaitan langsung dalam penyusunan laporan keuangan pada koperasi syariah yang bersangkutan. Teknik wawancara yang digunakan penulis adalah wawancara terstruktur. Wawancara terstruktur adalah tanya jawab yang berpedoman pada pertanyaan yang telah disusun secara sistematis oleh penulis.

d. Dokumentasi, yaitu melakukan pengumpulan data pendukung untuk memperkuat penelitian, yaitu berupa laporan keuangan, dokumen-dokumen atau catatan, formulir pembiayaan dan brosur, yang berhubungan dengan pembiayaan murabahah pada koperasi syariah di Aceh Besar.

\section{Instrumen Penelitian}

Instrumen penelitian yang digunakan adalah kuesioner yang disusun berdasarkan pengakuan, pengukuran, penyajian dan pengungkapan pada PSAK 102. diklasifikasikan dan diseleksi untuk memastikan data yang didapat tersebut benar-benar relevan.

b. Mengkaji kembali data-data murabahah yang telah diseleksi tersebut.

c. Menyajikan data berupa teori-teori yang berkaitan dengan PSAK 102 sehingga memudahkan dalam menganalisa data.

d. Menganalisa data dengan membandingkan dan menyesuaikan PSAK 102 dengan konsep, pelaksanaan, dan penerapan PSAK 102 pada 
transaksi murabahah tersebut. Pada data kuesioner, analisa data dilakukan dengan menghitung skor capaian, hasil persentase untuk mengetahui seberapa besar tingkat penerapan PSAK 102 pada koperasi syariah tersebut.

e. Memberikan penjelasan dan penjabaran kembali dengan deskriptif verifikasi.

f. Menarik kesimpulan dan memberikan saran-saran terhadap hasil analisis. Penarikan kesimpulan adalah proses akhir dari kegiatan analisis dalam data kualitatif. Penarikan kesimpulan merupakan sebuah esensi dari analisis data, suatu poin yang memberi makna atas data penelitian (Sekaran \& Bougie, 2016:349).

\section{Hasil dan Pembahasan}

\section{Pelaksanaan Pembiayaan Murabahah Pada} Koperasi di Aceh Besar

Koperasi syariah yang ada di Aceh Besar, yakni BQ Al-Istiqamah, Koperasi Syariah Mandiri Darussalam, Koperasi Syariah Mitra Niaga, BQ Karya Insan Sejahtera, Koperasi Simpan Pinjam Dana Mandiri Syariah dan BQ Abu Indrapuri, telah menjalankan perannya sebagai lembaga keuangan yang diperuntukkan bagi masyarakat kecil menengah ke bawah yang ingin membuka usaha yang produktif dan yang ingin melakukan investasi untuk meningkatkan kegiatan ekonomi pengusaha kecil dengan menggunakan prosedur yang tidak rumit. Pembiayaan yang sering disalurkan oleh koperasi syariah di Aceh Besar adalah pembiayaan murabahah karena risiko pembiayaan yang akan ditanggung koperasi syariah relatif kecil dibandingkan dengan pembiayaan yang lainnya. Untuk menghindari risiko ini terdapat penyimpangan yang terjadi, seperti penggunaan akad murabahah pada transaksi yang salah.

Pada hakikatnya, akad murabahah merupakan akad jual beli barang yang diketahui harga perolehannya beserta keuntungannya. Salah satu contoh kesalahan penggunaan akad yang terjadi adalah pihak koperasi membiayai modal usaha dagang yang diajukan nasabah, yang mana transaksi ini tidak seharusnya menggunakan akad murabahah karena tidak memenuhi unsur kepemilikan. Transaksi murabahah ini dilakukan dengan menggunakan wakalah yang mana membeli barang dagangan diwakilkan kepada nasabah agar nasabah dapat membeli barang yang diinginkan dan sesuai pula dengan permohonan yang diajukan kepada koperasi syariah. Namun akad wakalah ini dilakukan setelah akad murabahah, hal ini bertentangan dengan konsep syariah. Seharusnya akad wakalah ini dilakukan sebelum akad murabahah, sehingga setelah nasabah mewakilkan koperasi syariah untuk membeli barang dagangannya, pihak koperasi telah memiliki barang tersebut sepenuhnya dan setalah itu akad murabahah dapat dilakukan.

Transaksi seperti masih terjadi di koperasi syariah di Aceh Besar dengan alasan untuk memudahkan pihak-pihak yang bertransaksi baik pihak koperasi syariah maupun anggota atau masyarakat. Pihak koperasi syariah hanya memenuhi keinginan kebanyakan masyarakat yang merasa kesulitan jikalau harus kembali lagi ke koperasi syariah setelah barang dibeli untuk melakukan akad murabahah. Namun seharusnya transaksi seperti ini diperbaiki dari segi prosedurnya agar sesuai dengan konsep ekonomi syariah yang berlaku.

\section{Pengakuan dan Pengukuran Pembiayaan Murabahah}

Perlakuan akuntansi atas pengakuan dan pengukuran pada BQ Al-Istiqamah, Koperasi Syariah Mandiri Darussalam, , BQ Karya Insan Sejahtera 43 dan BQ Abu Indrapuri telah sesuai dengan PSAK 102, sedangkan perlakuan akuntansi atas pengakuan dan pengukuran pada KSP Dana Mandiri Syariah dan Koperasi Syariah Mitra Niaga belum sepenuhnya sesuai. Hal tersebut dapat dilihat pada Tabel 2.

Berdasarkan perhitungan pada Tabel 2 dapat dilihat bahwa perlakuan akuntansi atas pengakuan dan pengukuran pada BQ Al-Istiqamah, Koperasi Syariah Mandiri Darussalam, Kopsyah BQ Karya Insan Sejahtera 43 dan Kopsyah BQ Abu Indrapuri 100\% telah sesuai dengan PSAK 102. Koperasi Syariah Mitra Niaga dan KSP Dana Mandiri Syariah dengan tingkat kesesuaian atas pengakuan 90\% dikarenakan mereka tidak mengakui diskon pembelian aset murabahah. 
Tabel 2

Tingkat Persentase Kesesuaian Penerapan PSAK 102 atas Pengakuan dan Pengukuran

\begin{tabular}{|l|lr|c|c|}
\hline No. & \multicolumn{2}{|l|}{ Koperasi Syariah } & $\begin{array}{c}\text { Perhitungan } \\
\text { Skor Capaian }\end{array}$ & Hasil \\
\hline 1. & \multicolumn{2}{|l|}{ BQ Al-Istiqamah } & $\frac{10}{10} \times 100 \%$ & $100 \%$ \\
\hline 2. & $\begin{array}{l}\text { Koperasi Syariah } \\
\text { Mandiri Darussalam }\end{array}$ & $\frac{10}{10} \times 100 \%$ & $100 \%$ \\
\hline 3. & $\begin{array}{l}\text { Koperasi Syariah } \\
\text { Mitra Niaga }\end{array}$ & $\frac{9}{10} \times 100 \%$ & $90 \%$ \\
\hline 4. & $\begin{array}{l}\text { BQ Karya Insan } \\
\text { Sejahtera 43 }\end{array}$ & $\frac{10}{10} \times 100 \%$ & $100 \%$ \\
\hline 5. & $\begin{array}{l}\text { KSP Dana Mandiri } \\
\text { Syariah }\end{array}$ & $\frac{9}{10} \times 100 \%$ & $90 \%$ \\
\hline 6. & \multicolumn{2}{|l|}{ BQ Abu Indrapuri } & $\frac{10}{10} \times 100 \%$ & $100 \%$ \\
\hline
\end{tabular}

Sumber: Data Diolah 2019

\section{Penyajian Pembiayaan Murabahah}

Perlakuan akuntansi atas penyajian pembiayaan murabahah pada BQ Al-Istiqamah, Koperasi Syariah Mandiri Darussalam, Koperasi Syariah Mitra Niaga, BQ Karya Insan Sejahtera 43, KSP Dana Mandiri Syariah dan BQ Abu Indrapuri sudah sesuai dengan PSAK 102. Hal tersebut dapat dilihat dalam Tabel 3.

Tabel 3

Tingkat Persentase Kesesuaian Penerapan PSAK 102 atas Penyajian

\begin{tabular}{|l|l|c|c|}
\hline No. & Koperasi Syariah & $\begin{array}{l}\text { Perhitungan } \\
\text { Skor Capaian }\end{array}$ & Hasil \\
\hline 1. & BQ Al-Istiqamah & $\frac{2}{2} \times 100 \%$ & $100 \%$ \\
\hline 2. & $\begin{array}{l}\text { Koperasi Syariah } \\
\text { Mandiri Darussalam }\end{array}$ & $\frac{2}{2} \times 100 \%$ & $100 \%$ \\
\hline 3. & $\begin{array}{l}\text { Koperasi Syariah } \\
\text { Mitra Niaga }\end{array}$ & $\frac{2}{2} \times 100 \%$ & $100 \%$ \\
\hline 4. & $\begin{array}{l}\text { BQ Karya Insan } \\
\text { Sejahtera 43 }\end{array}$ & $\frac{2}{2} \times 100 \%$ & $100 \%$ \\
\hline 5. & $\begin{array}{l}\text { KSP Dana Mandiri } \\
\text { Syariah }\end{array}$ & $\frac{2}{2} \times 100 \%$ & $100 \%$ \\
\hline 6. & BQ Abu Indrapuri & $\frac{2}{2} \times 100 \%$ & $100 \%$ \\
\hline
\end{tabular}

Sumber: Data Diolah 2019
Berdasarkan perhitungan pada Tabel 3 dapat dilihat bahwa penyajian pembiayaan murabahah pada BQ Al-Istiqamah, Koperasi Syariah Mandiri Darussalam, Koperasi Syariah Mitra Niaga, BQ Karya Insan Sejahtera 43, KSP Dana Mandiri Syariah dan BQ Abu Indrapuri telah sesuai dengan PSAK 102.

\section{Pengungkapan}

Perlakuan akuntansi atas pengungkapan pada BQ Al-Istiqamah, Koperasi Syariah Mandiri Darussalam, Koperasi Syariah Mitra Niaga, BQ Karya Insan Sejahtera 43, KSP Dana Mandiri Syariah dan BQ Abu Indrapuri telah sesuai dengan PSAK 102. Hal tersebut dapat dilihat pada Tabel 4.

Tabel 4

Tingkat Persentase Kesesuaian Penerapan PSAK 102 atas Pengungkapan

\begin{tabular}{|c|c|c|c|}
\hline No. & Koperasi Syariah & $\begin{array}{l}\text { Perhitungan } \\
\text { Skor Capaian }\end{array}$ & Hasil \\
\hline 1. & BQ Al-Istiqamah & $\frac{3}{3} \times 100 \%$ & $100 \%$ \\
\hline 2. & $\begin{array}{l}\text { Koperasi Syariah } \\
\text { Mandiri Darussalam }\end{array}$ & $\frac{3}{3} \times 100 \%$ & $100 \%$ \\
\hline 3. & $\begin{array}{l}\text { Koperasi Syariah Mitra } \\
\text { Niaga }\end{array}$ & $\frac{3}{3} \times 100 \%$ & $100 \%$ \\
\hline 4. & $\begin{array}{l}\text { BQ Karya Insan } \\
\text { Sejahtera } 43\end{array}$ & $\frac{3}{3} \times 100 \%$ & $100 \%$ \\
\hline 5. & $\begin{array}{l}\text { KSP Dana Mandiri } \\
\text { Syariah }\end{array}$ & $\frac{3}{3} \times 100 \%$ & $100 \%$ \\
\hline 6. & BQ Abu Indrapuri & $\frac{3}{3} \times 100 \%$ & $100 \%$ \\
\hline
\end{tabular}

Sumber: Data Diolah 2019

Berdasarkan Tabel 4 dapat dilihat bahwa hasil skor capaian penerapan PSAK 102 atas pengungkapan yang didapat oleh BQ Al-Istiqamah, Koperasi Syariah Mandiri Darussalam, Koperasi Syariah Mitra Niaga, BQ Karya Insan Sejahtera 43, KSP Dana Mandiri Syariah dan BQ Abu Indrapuri adalah 100\%. Dapat disimpulkan bahwa keenam koperasi syariah telah mengungkapkan hal-hal yang diperlukan sesuai dengan PSAK 102 yaitu keenam koperasi telah mengungkapkan harga perolehan aset murabahah dan janji pemesan dalam murabahah. Keenam koperasi juga telah mengungkapkan laporan keuangan syariah berdasarkan PSAK 101. 


\section{Kesimpulan, Keterbatasan dan saran Kesimpulan}

Kesimpulan dari penelitian ini adalah sebagai berikut.

1. Pelaksanaan pembiayaan murabahah di enam koperasi syariah di Aceh Besar, yakni BQ AlIstiqamah, Koperasi Syariah Mandiri Darussalam, Koperasi Syariah Mitra Niaga, BQ Karya Insan Sejahtera 43, Koperasi Simpan Pinjam Dana Mandiri Syariah dan BQ Abu Indrapuri, telah menggunakan prosedur pembiayaan yang tidak rumit sehingga masyarakat yang memiliki usaha mikro menengah ke bawah dapat melakukan pembiayaan di koperasi- koperasi tersebut. Namun masih ada koperasi syariah yang menempatkan akad murabahah dalam transaksi yang salah sehingga tidak terpenuhinya rukun jual beli. Akad wakalah yang diterapkan untuk melakukan pembelian barang juga belum sesuai dengan ketentuan ekonomi Islam. Seharusnya akad wakalah dilakukan sebelum akad murabahah terjadi.

2. Perlakuan akuntansi atas pengakuan dan pengukuran pembiayaan murabahah pada Baitul Qiradh Al-Istiqamah, Koperasi Syariah Mandiri Darussalam, Baitul Qiradh Karya Insan Sejahtera 43, dan Baitul Qiradh Abu Indrapuri telah sesuai dengan PSAK 102, sedangkan Koperasi Syariah Mitra Niaga dan Koperasi Simpan Pinjam Dana Mandiri Syariah belum sepenuhnya sesuai, ketidaksesuaian terletak pada diskon pembelian aset murabahah tidak diakui oleh pihak koperasi. Perlakuan akuntansi atas penyajian pembiayaan murabahah pada keenam koperasi syariah di Aceh Besar, yakni BQ Al-Istiqamah, Koperasi Syariah Mandiri Darussalam, Koperasi Syariah Mitra Niaga, BQ Karya Insan Sejahtera 43, Koperasi Simpan Pinjam Dana Mandiri Syariah dan BQ Abu Indrapuri, telah sesuai dengan PSAK 102. Perlakuan akuntansi atas pengungkapan pembiayaan murabahah pada keenam koperasi syariah di Aceh Besar telah sesuai dengan PSAK 102.

\section{Keterbatasan}

Keterbatasan-keterbatasan dalam penelitian ini, yaitu:
1. Penelitian ini masih terbatas penerapan PSAK 102 pada pengakuan, pengukuran, penyajian, dan pengungkapan pembiayaan murabahah, dalam penelitian tidak membahas prosedur pembiayaan murabahah secara keseluruhan.

2. Data dan informasi yang didapatkan peneliti pada beberapa koperasi masih sedikit sehingga mempersulit dalam menganalisa kesesuaian penerapan PSAK 102.

3. Masih kurangnya pengetahuan SDM koperasi syariah tentang PSAK Syariah, terutama PSAK 102 yang mengatur tentang akuntansi murabahah.

\section{Saran}

Saran untuk peneliti selanjutnya dan para praktisi, yaitu:

1. Pada peneliti selanjutnya diharapkan dapat menambah ruang lingkup penelitian, tidak terbatas pada pengakuan, pengukuran, penyajian, dan pengungkapan dan pada prosedur transaksi murabahah.

2. Koperasi syariah di Aceh Besar diharapkan menggunakan akad murabahah dan akad wakalah pada transaksi yang benar.

3. Koperasi syariah di Aceh Besar diharapkan dapat menerapkan sistem syariah secara keseluruhan terhadap perlakuan akuntansinya.

4. Dinas koperasi dan UMKM Aceh Besar diharapkan dapat memberikan pelatihan tentang PSAK syariah dan memberikan kebijakan baru untuk menerapkan sistem akuntansi yang syariah kepada koperasi-koperasi syariah di Aceh Besar

\section{Daftar Pustaka}

Budiono, A. (2017). Penerapan Prinsip Syariah Pada Lembaga Keuangan Syariah. Junal Law and Justice.

Darsono, dkk. (2017). Dinamika Produk dan Akad Keuangan Syariah di Indonesia. Depok: Rajawali Pers.

Hasyim, H. (2018). Regulasi dan Eksistensi Koperasi Syariah Di Kota Depok. Jurnal Ekonomi dan Bisnis Islam.

Ikatan Akuntan Indonesia. (2018). Pernyataan Standar Akuntansi Keuangan 102: Akuntansi 
Murabahah. Melalui: iaiglobal.or.id. Diakses 3 Maret 2019.

Ikhsan, A., \& Haridhi, M. (2017). Penerapan Standar Akuntansi Keuangan Syariah Pada Koperasi Jasa Keuangan Syariah (Studi Pada Baitul Qiradh Di Kota Banda Aceh). Jurnal Ilmiah Mahasiswa Ekonomi Akuntansi (JIMEKA).

Kementerian Koperasi dan UKM. (2016). Kinerja Koperasi Syariah Di Indonesia Sangat Baik. Melalui: http://www.depkop.go.id. Diakses 13 November 2018.

(2018). Nomor Induk Koperasi. Melalui: nik.depkop.go.id. Diakses 25 Januari 2019.

Mardani. (2015). Aspek Hukum Lembaga Keuangan Syariah di Indonesia. Jakarta: Kencana.

Mardani. (2015). Fiqih Ekonomi Syari'ah. Jakarta: Kencana.

Marlina, R., \& Pratami, Y. Y. (2017). Koperasi Syariah Sebagai Solusi Penerapan Akad Syirkah yang Sah. Jurnal Amwaluna.

Nurhayati, S., \& Wasilah. (2015). Akuntansi Syariah Di Indonesia. Jakarta: Salemba Empat.

Otoritas Jasa Keuangan. (2018). Statistik IKNB Syariah Periode Desember 2018. Melalui: www.ojk.go.id. Diakses 3 Maret 2019.

Republik Indonesia. Undang-undang No. 10 Tahun 1998 Tentang Perubahan Atas UndangUndang No. 7 Tahun 1992 Tentang perbankan.

. Undang-Undang No.17 tahun 2012 tentang Perkoperasian.

Sekaran, U., \& Bougie, R. (2016). Research Method For Business: A Skill Building Approach, Sixth Edition. Jakarta: Salemba Empat.

Soemitra, A. (2015). Bank dan Lembaga Keuangan Syariah. Jakarta: Kencana.

Sugiyono. (2013). Metode Penelitian Kuantitatif, Kualitatif, dan $R \& D$. Bandung: Alfabeta.

Sulaiman, S. (2016). Penyimpangan Akad Murabahah Pada Perbankan Syariah di Indonesia. Jurnal Ekonomi Syariah.
Virtianto, Y. M., Fathoni, A., Magdalena, M. (2018). The Analysis of Variable-Variable Marketing Mix To Customer Loyalty (Study on Koperasi Simpan Pinjan Tirta Danarta Semarang). Journal of Management.

Yaya, R., Martawireja, A. E., \& Abdurahim, A. (2017). Akuntansi Perbankan Syariah: Teori dan Praktik Kontemporer. Jakarta: Salemba Empat. 